\title{
REVIEW
}

\section{Current applications of multiparameter flow cytometry in plasma cell disorders}

\author{
This article has been corrected since Online Publication and an Erratum has also been published
}

T Jelinek ${ }^{1,2,3}$, R Bezdekova ${ }^{4}$, M Zatopkova ${ }^{2}$, L Burgos ${ }^{3}$, M Simicek², T Sevcikova ${ }^{2}$, B Paiva ${ }^{3}$ and R Hajek ${ }^{1,2}$

\begin{abstract}
Multiparameter flow cytometry (MFC) has become standard in the management of patients with plasma cell (PC) dyscrasias, and could be considered mandatory in specific areas of routine clinical practice. It plays a significant role during the differential diagnostic workup because of its fast and conclusive readout of PC clonality, and simultaneously provides prognostic information in most monoclonal gammopathies. Recent advances in the treatment and outcomes of multiple myeloma led to the implementation of new response criteria, including minimal residual disease (MRD) status as one of the most relevant clinical endpoints with the potential to act as surrogate for survival. Recent technical progress led to the development of next-generation flow (NGF) cytometry that represents a validated, highly sensitive, cost-effective and widely available technique for standardized MRD evaluation, which also could be used for the detection of circulating tumor cells. Here we review current applications of MFC and NGF in most PC disorders including the less frequent solitary plasmocytoma, light-chain amyloidosis or Waldenström macroglobulinemia.
\end{abstract}

Blood Cancer Journal (2017) 7, e617; doi:10.1038/bcj.2017.90; published online 20 October 2017

\section{INTRODUCTION}

Plasma cell (PC) dyscrasias are a heterogeneous group of blood disorders characterized by the detection of a monoclonal paraprotein in serum or urine, which is often associated with the presence of clonal PCs in the bone marrow (BM) and eventually other tissues. ${ }^{1}$ With an estimated incidence of 6 cases per 100000 persons per year, multiple myeloma (MM) represents the second most common hematologic malignancy and $\sim 1 \%$ of all malignant tumors. ${ }^{2} \mathrm{MM}$ is characterized by the presence of $>10 \%$ of clonal BM PCs (based on morphological assessment) or biopsy-proven plasmocytoma, together with at least one of the so called 'myeloma defining events'. ${ }^{3}$ Myeloma is virtually always preceded by an asymptomatic premalignant stage termed monoclonal gammopathy of undetermined significance (MGUS) that is present in about 3-4\% of normal individuals over the age of 50 years. ${ }^{4,5}$ The risk of progression of MGUS to MM or related disorders is about $1 \%$ per year. ${ }^{6,7}$ Smoldering multiple myeloma (SMM) represents an intermediate clinical stage between MGUS and $M M$ in which the risk of progression to malignant disease in the first 5 years after diagnosis is much higher, about 10\% per year. $^{3,8}$ Amongst other, less frequent, PC dyscrasias there are: (i) plasma cell leukemia (PCL), (ii) $A L$ amyloidosis ( $A L$ ), (iii) Waldenström macroglobulinemia (WM), (iv) POEMS syndrome and $(v)$ solitary plasmocytoma with or without minimal BM involvement (Table 1).

Multiparameter flow cytometry (MFC) immunophenotyping has been a mainstay in the diagnosis and monitoring of most hematologic malignancies. ${ }^{9-13}$ Together, with the patient's clinical history, analytic results and morphological assessment of blood smears, MFC is also part of the initial diagnostic work-up, mainly because of its capacity to typically provide conclusive results within a few hours. As the importance of MFC has progressively increased in PC dyscrasias (Figure 1), its utility will be thoroughly reviewed in this manuscript.

\section{DETECTION OF NORMAL AND PATHOLOGICAL PLASMA CELLS} Identification and enumeration of the PC compartment The first step during the analysis of patients with PC dyscrasias at diagnosis and during follow-up is represented by the identification and enumeration of the PC compartment. PCs are end-stage antibody producing B-cells that are derived from antigenactivated B-cells generated in secondary lymphoid tissues. Early-stage PCs (generally called plasmablasts) can be found in peripheral blood $(\mathrm{PB})$ during their recirculation from the tissues of origin seeking for survival niches (for example, in BM) where they evolve to long-living PCs. Plasmablasts lose CD20, express CD19, CD38 high, CD45 and approximately half of them show reactivity for $\mathrm{CD} 138 .^{14}$ Although $\mathrm{CD} 38$ is a very promiscuous antigen ubiquitously expressed on all immune cells, its intensity is uniquely high on $\mathrm{PCs},{ }^{15}$ making it a reliable marker for $\mathrm{PC}$ gating. Conversely, CD138 (Syndecan-1) is specific to PCs (within hematopoietic cells) and, accordingly, has been found very useful in their identification. These two markers together with CD45, sideward (SSC) and forward (FSC) light scatter are recommended for accurate identification and enumeration of $\mathrm{PCs}{ }^{16,17}$

\footnotetext{
${ }^{1}$ Department of Haematooncology, University Hospital Ostrava and Faculty of Medicine, University of Ostrava, Ostrava, Czech Republic; ${ }^{2}$ Faculty of Science, University of Ostrava, Ostrava, Czech Republic; ${ }^{3}$ Clinica Universidad de Navarra, Centro de Investigacion Medica Aplicada (CIMA), IDISNA, Pamplona, Spain and ${ }^{4}$ Department of Clinical Haematology, University Hospital Brno, Brno, Czech Republic. Correspondence: Dr T Jelinek, Department of Haematooncology University Hospital Ostrava, 17.listopadu 1790, Ostrava 708 52, Czech Republic.
} 
Table 1. Definitions of plasma cell related disorders (adopted from Rajkumar et al., ${ }^{3}$ )

\begin{tabular}{|c|c|}
\hline Title & Def \\
\hline MGUS & $\begin{array}{l}\text { Serum monoclonal protein (non-lgM type) }<30 \mathrm{~g} / \mathrm{l} \\
\text { Clonal bone marrow plasma cells }<10 \% \\
\text { Absence of end-organ damage such as hypercalcaemia, renal insufficiency, anaemia, and bone lesions (CRAB) or amyloidosis that } \\
\text { can be attributed to the plasma cell proliferative disorder }\end{array}$ \\
\hline SMM & $\begin{array}{l}\text { Both criteria must be met: } \\
\text { - Serum monoclonal protein ( } \operatorname{lgG} \text { or } \lg \mathrm{A}) \geqslant 30 \mathrm{~g} / \mathrm{l} \text { or urinary monoclonal protein } \geqslant 500 \mathrm{mg} \text { per } 24 \mathrm{~h} \text { and/or clonal bone } \\
\text { marrow plasma cells } 10-60 \% \\
\text { - Absence of myeloma defining events or amyloidosis }\end{array}$ \\
\hline MM & $\begin{array}{l}\text { Clonal bone marrow plasma cells } \geqslant 10 \% \text { or biopsy-proven bony or extramedullary plasmacytoma } \\
\text { Evidence of any of myeloma defining events }\end{array}$ \\
\hline $\mathrm{PCL}$ & $\begin{array}{l}\text { Presence of }>20 \% \text { of clonal plasma cells in peripheral blood and/or the absolute number of circulating plasma cells exceeding } \\
2 \times 10^{9} / \mathrm{I} \text { in peripheral blood }\end{array}$ \\
\hline Solitary & Biopsy-proven solitary lesion of bone or soft tissue with evidence of clonal plasma cells \\
\hline Plasmacytoma & $\begin{array}{l}\text { Normal bone marrow with no evidence of clonal plasma cells } \\
\text { Normal skeletal survey and MRI (or CT) of spine and pelvis (except for the primary solitary lesion) } \\
\text { Absence of end-organ damage such as hypercalcaemia, renal insufficiency, anaemia, or bone lesions (CRAB) that can be } \\
\text { attributed to a lymphoplasma cell proliferative disorder }\end{array}$ \\
\hline Light-chain & Abnormal FLC ratio $(<0.26$ or $>1.65)$ \\
\hline MGUS & $\begin{array}{l}\text { Increased level of the appropriate involved light chain (increased } \kappa \text { FLC in patients with ratio }>1.65 \text { and increased } \lambda \text { FLC in } \\
\text { patients with ratio }<0 \cdot 26 \text { ) } \\
\text { No immunoglobulin heavy chain expression on immunofixation } \\
\text { Absence of end-organ damage such as hypercalcaemia, renal insufficiency, anaemia, and bone lesions (CRAB) or amyloidosis that } \\
\text { can be attributed to the plasma cell proliferative disorder } \\
\text { Clonal bone marrow plasma cells }<10 \% \\
\text { Urinary monoclonal protein }<500 \mathrm{mg} / 24 \mathrm{~h}\end{array}$ \\
\hline$A L$ & $\begin{array}{l}\text { Presence of an amyloid-related systemic syndrome (eg, renal, liver, heart, gastrointestinal tract, or peripheral nerve involvement) } \\
\text { Positive amyloid staining by Congo red in any tissue (eg, fat aspirate, bone marrow, or organ biopsy) } \\
\text { Evidence that amyloid is light-chain-related established by direct examination of the amyloid using mass spectrometry-based } \\
\text { proteomic analysis, or immunoelectronmicroscopy } \\
\text { Evidence of a monoclonal plasma cell proliferative disorder (serum or urine monoclonal protein, abnormal free light-chain ratio, } \\
\text { or clonal plasma cells in the bone marrow) }\end{array}$ \\
\hline IgM-MGUS & $\begin{array}{l}\text { Serum IgM monoclonal protein }<30 \mathrm{~g} / \mathrm{l} \\
\text { Bone marrow lymphoplasmacytic infiltration }<10 \% \\
\text { No evidence of anemia, constitutional symptoms, hyperviscosity, lymphadenopathy, hepatosplenomegaly or other end-organ } \\
\text { damage that can be attributed to the underlying lymphoproliferative disorder }\end{array}$ \\
\hline Smoldering WM & $\begin{array}{l}\text { Presence of serum IgM monoclonal protein } \\
\text { Bone marrow lymphoplasmacytic infiltration }>10 \% \\
\text { No evidence of anaemia, constitutional symptoms, hyperviscosity, lymphadenopathy, hepatosplenomegaly, or other end-organ } \\
\text { damage that can be attributed to the underlying lymphoproliferative disorder }\end{array}$ \\
\hline WM & $\begin{array}{l}\text { Presence of serum IgM monoclonal protein } \\
\text { Bone marrow lymphoplasmacytic infiltration }>10 \% \\
\text { Evidence of anaemia, constitutional symptoms, hyperviscosity, lymphadenopathy, hepatosplenomegaly, or other end-organ } \\
\text { damage that can be attributed to the underlying lymphoproliferative disorder }\end{array}$ \\
\hline POEN & Polyneuropathy \\
\hline Syndrome & $\begin{array}{l}\text { Monoclonal plasma cell proliferative disorder (almost always } \lambda \text { ) } \\
\text { Any one of the following three other major criteria: } \\
\text { - Sclerotic bone lesions } \\
\text { - Estleman's disease } \\
\text { Any one of the following six minor criteria: } \\
\text { - Organomegaly (splenomegaly, hepatomegaly, or lymphadenopathy) } \\
\text { - Extravascular volume overload (oedema, pleural eff usion, or ascites) } \\
\text { - Skin changes (hyperpigmentation, hypertrichosis, glomeruloid haemangiomata, plethora, acrocyanosis, flushing, white } \\
\text { - nails) } \\
\text { - Thilloedema }\end{array}$ \\
\hline
\end{tabular}

Immunophenotypic discrimination between normal vs pathologic plasma cells

It should be noted that no single phenotypic marker is sufficient to distinguish between normal/reactive plasma cells vs tumor plasma cells. Most BM normal PCs do not express pan B-cell markers such as CD20 or CD22, lack surface membrane immunoglobulins (smlg) and show polyclonal cytoplasmatic staining of light chains (cyKappa, cyLambda). Moreover, normal PCs show heterogeneous expression of CD19, CD27, CD45 and CD81. Thus, among normal BM PCs there are several phenotypically distinct subpopulations that display maturation-associated features according to the most commonly used markers CD19, CD27, CD45, CD56 and CD81. The majority of normal BM PCs are $\mathrm{CD} 19^{+}, \mathrm{CD} 45^{\mathrm{dim}}, \mathrm{CD} 56^{-}$and $\mathrm{CD} 81^{+}$, but $>30 \%$ of them are $\mathrm{CD} 19^{-}, \mathrm{CD} 45^{+}, \mathrm{CD} 56^{+}$or $\mathrm{CD} 81^{-}$, in multiple possible combinations. ${ }^{17,18}$

There is compelling evidence that tumor PCs display different phenotypic features as compared to their normal counterparts. It was reported in 1998 a correlation between the presence of abnormal phenotypes detectable by flow cytometry, and the presence of tumor, clonal PCs; accordingly, fluorescent-activated 


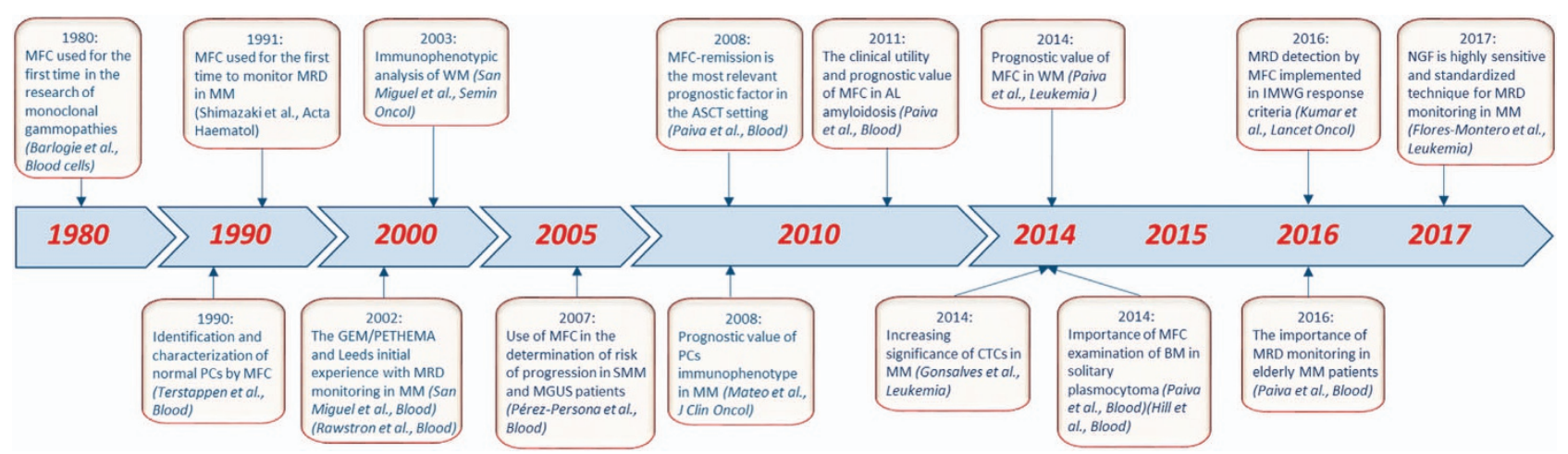

Figure 1. Time axis highlighting the most important discoveries concerning multiparameter flow cytometry and its use in plasma cell dyscrasias.

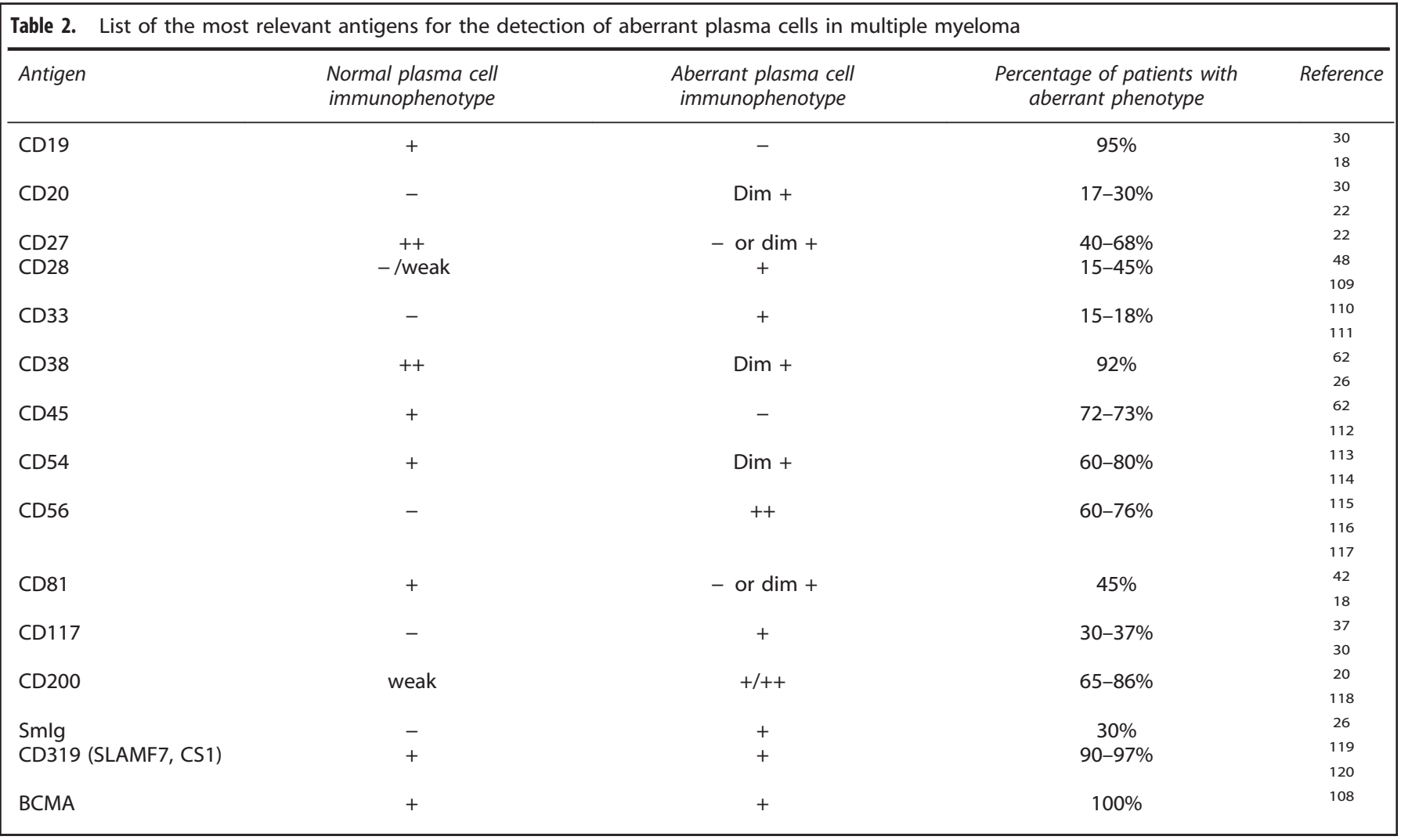

cell sorting (FACS) of PCs with aberrant vs normal phenotypes (for example, bright expression of CD56) correlated with clonal vs polyclonal PCR V-D-JH products. ${ }^{19}$ Additional studies confirmed that tumor PCs typically show: (i) underexpression of CD19, CD27, CD38, CD45 and CD81, (ii) overexpression of CD28, CD33, CD56, CD117 and CD200 and (iii) asynchronous expression of CD20 and Smlg. ${ }^{17,20-22}$ Except for CD117 that is almost never expressed on normal PCs, most of the expression patterns defined above can be found, individually (that is, not simultaneously), in small subsets of nPCs. This has become particularly evident with the advent of digital flow cytometers allowing for multidimensional combinations together with faster acquisitions and the measurement of higher number of cells. For example, it has been recently suggested that long-lived PCs downregulated CD19, CD38, CD45, CD81 and upregulated CD28 and CD56, which are some of the phenotypic hallmarks of tumor PCs. In fact, it could be speculated that such long-lived PCs could represent the normal cellular counterpart of many MM patients. Thus, it is currently recommended that the clonal nature of tumor PCs as defined by MFC, should be confirmed by the presence of simultaneous and multiple aberrant phenotypes together ${ }^{23}$ defined PC subsets with such aberrant phenotypes. Frequencies of these abnormal patterns of expression are summarized in Table 2.

\section{Practical considerations}

It is well-accepted that the percentage of PCs is usually underrepresented by MFC as compared to other cytologic methods. While there are several factors that could be responsible for this phenomenon, the most probable explanation is that tumor PCs are associated with lipid enriched BM spicules in the morphology slides, as opposed to lipid-depleted liquid BM analyzed by MFC. ${ }^{24}$ That notwithstanding, higher PB hemodilution has typically 
characterized BM samples devoted to MFC (and other laboratory tests), as the first BM pull has been dedicated to morphology slides. Highly representative and non-diluted BM samples are crucial for valid and precise results particularly during MRD evaluation, and it is highly recommendable to use the first BM pull for flow-based MRD assessment. Another factor resulting in the underestimation of BM PCs is the loss of PCs during sample preparation due to the potentially higher susceptibility of PCs for mechanical damage. ${ }^{22}$ Accordingly, we recommend the adoption of methods that have been extensively validated and demonstrated superior PC recovery as compared to other methods. ${ }^{23}$ It should be noted though that most current applications of MFC take place in disease stages or disease entities in which PCs are $<1 \%$ of total nucleated BM cells and in which a mixture of normal and tumor PCs coexist, making it the only cytologic technique with enough sensitivity for accurate quantification and characterization of tumor PCs.

\section{THE TRANSITION FROM MGUS TO SMOLDERING AND ACTIVE MM}

Role of MFC in differential diagnosis

From a clinical point of view, one of the most evident roles of routine MFC is during patients' differential diagnostic work-up. First, to distinguish between prominent but reactive and benign plasmocytosis vs clonal and potentially malignant PC dyscrasias. ${ }^{25}$ Second, to recognize B-cell non-Hodgkin lymphomas (B-NHL) with extensive plasmacytic differentiation such as lymphoplasmacytic lymphoma (LPL, WM) or marginal zone lymphoma (MZL). The distinction can be made by careful identification of small B-cell clones that may be below the limit of detection of morphology or immunohistochemistry $(\mathrm{IHC})$, together with comprehensive evaluation of the phenotypic profile of tumor $\mathrm{PCs}^{26}$ Third, to confirm the diagnosis of rare IgM myeloma cases based on distinct PC phenotype from other lgM producing B-cell disorders. ${ }^{25}$ Fourth, to help discriminate between MGUS vs SMM vs active MM based on the percentage of $\mathrm{nPCs}$ within the bone marrow PC (BMPC) compartment. Twenty years have passed since Ocqueteau et al. described that MGUS is characterized by the co-existence of normal PCs and tumor PCs (100\% of cases) whereas in MM this finding is less frequent ( $22 \%$ of cases). Moreover, only $1.5 \%$ of MM patients had more than $3 \%$ of nPCs, whereas $98 \%$ of MGUS patients had more than $3 \%$ of nPCs. Therefore, a proposed cut-off of $>5 \%$ of residual normal PCs (within the BMPC compartment) has been found to help in the discrimination between MGUS and active MM. ${ }^{19,27,28}$ That notwithstanding, one of the most useful applications of this threshold has been found in SMM, in which it would allow to discriminate patients with MGUS-like vs MM-like phenotypic profiles and different risk of progression. $^{29,30}$

\section{Role of MFC in providing prognostic information}

Prognostic information provided by MFC-based evaluation of the BM PC compartment is not that widely used as other prognostic factors such as International staging system (ISS), cytogenetic abnormalities or lactate dehydrogenase. ${ }^{31-33}$ Nevertheless, there is growing evidence suggesting that MFC can be useful to: (i) predict the risk of transformation of MGUS and SMM into active MM; (ii) identify a small subgroup of symptomatic MM patients with an exceptionally favorable prognosis (that is, those with MGUS-like profile); and (iii) offer prognostic information based on the immunophenotype of tumor PCs. The prognostic value of circulating PCs (CTCs) will be reviewed in a separate chapter.

The model predicting the risk of transformation of MGUS and SMM into symptomatic MM was designed by the Spanish group and is based on the presence of $>95 \%$ of tumor PCs within the BM PC compartment. Thus, MGUS patients who fulfill this criterion had a cumulative probability of progression into symptomatic MM at 5 years of 25 vs $5 \%$ of those who had $<95 \%$ of tumor PCs. Similarly, using the same criterion in SMM patients, a cumulative probability of progression into active MM at 5 years was $64 \%$ vs only $8 \%{ }^{29,34}$ There are ongoing efforts to standardize MFC and develop automated models to predict risk of transformation in SMM. ${ }^{35}$ Conversely, a subgroup of newly diagnosed MM (NDMM) patients who have, at the time of diagnosis, more than $5 \%$ of residual normal PCs from all BM PCs, display unique clinical and biological characteristics such as lower BM infiltration by PCs, higher hemoglobin levels, lower frequency of immune paresis and others. Paiva et al. $^{36}$ have shown in a cohort of 594 uniformly treated NDMM patients, that this subgroup (14\% of analyzed patients) had significantly longer progression-free survival (median PFS, 54 vs 42 months, $P=.001$ ) and overall survival (median OS, not reached vs 89 months, $P=0.04$ ) than patients with $\leqslant 5 \%$ of normal PCs in the BM PC compartment. Driven by these observations, the Spanish Myeloma Group subsequently developed an automated flow cytometric algorithm that recognizes, amongst NDMM patients, those with the so-called MGUS-like phenotype that display a highly favorable prognosis. According to this algorithm, $8 \%$ of NDMM patients were identified with an MGUS-like profile. MGUS-like cases had unprecedented longer time-to-progression (TTP) and OS ( 60\% at 10 years; $P<0.001)$ rates. Importantly, MGUS-like MM patients failing to achieve complete remission (CR) showed similar TTP $(P=0.81)$ and OS $(P=0.24)$ vs cases attaining CR. In fact, identifying these patients could be clinically relevant because they may experience favorable outcomes (may not progress despite evidence of disease, as MGUS patients do) in the absence of CR. This group of patients may represent an exception to the rule: 'the deeper the response, the longer the survival' and should not be over-treated in pursuit of reaching deep responses. ${ }^{30}$ That notwithstanding, MGUS-like patients reaching MRD-negativity after first-line treatment have the best outcomes of all MM patients (median PFS of 12 years and a 10 -year OS rate of $94 \%){ }^{37}$

Many studies have been conducted to evaluate the prognostic significance of the immunophenotype of myeloma PCs, but only a few antigens have shown to be of prognostic value. CD117 (protooncogene c-KIT) is a receptor tyrosine kinase normally expressed by mast cells and hematopoietic progenitors in the BM, but absent during B-cell maturation from early precursors to PCs. ${ }^{38}$ This antigen is aberrantly over-expressed in $\sim 70 \%$ of MGUS patients and $30 \%$ of MM patients. Although its expression is related to oncogenic transformation in other malignancies, in $\mathrm{MM}$ it is associated with favorable outcomes. This occurs hypothetically because of the altered homing of clonal CD117+ PCs that are redirected towards the neutrophil precursor niches, thus giving space for maintenance of residual nPCs. ${ }^{39,40}$ Conversely, adverse prognosis is associated with expression of CD28 (T-cell costimulatory receptor) that is positive in approximately $35 \%$ of MM cases. This adverse effect was originally attributed to a strong association with high-risk cytogenetic abnormalities, but recently an alternative explanation has been proposed based on the prosurvival effect of plasma cell-dendritic cell interactions. ${ }^{39,41}$ According to Mateo et al., three separate risk groups can be identified based on the cohort of 685 uniformly treated NDMM patients: poor (CD28+/CD117-), intermediate (CD28+/CD117+ or CD28-/CD117-) and good (CD28-/CD117+) with corresponding median OS of 45 months, 68 months and not reached, respectively. This study also revealed an adverse prognostic role of CD19 (part of the B-cell receptor, expressed only in B-cell lineage) that is positive only in $5 \%$ of MM patients. ${ }^{39}$ The antigen CD19 is regulated by CD81 that is a glycoprotein from the tetraspanin family expressed in $45 \%$ of MM cases. Paiva et al. ${ }^{42}$ described and validated the expression of CD81 as a negative prognostic marker for symptomatic MM patients as well as a marker for the risk of progression in SMM patients. Recently, a new 


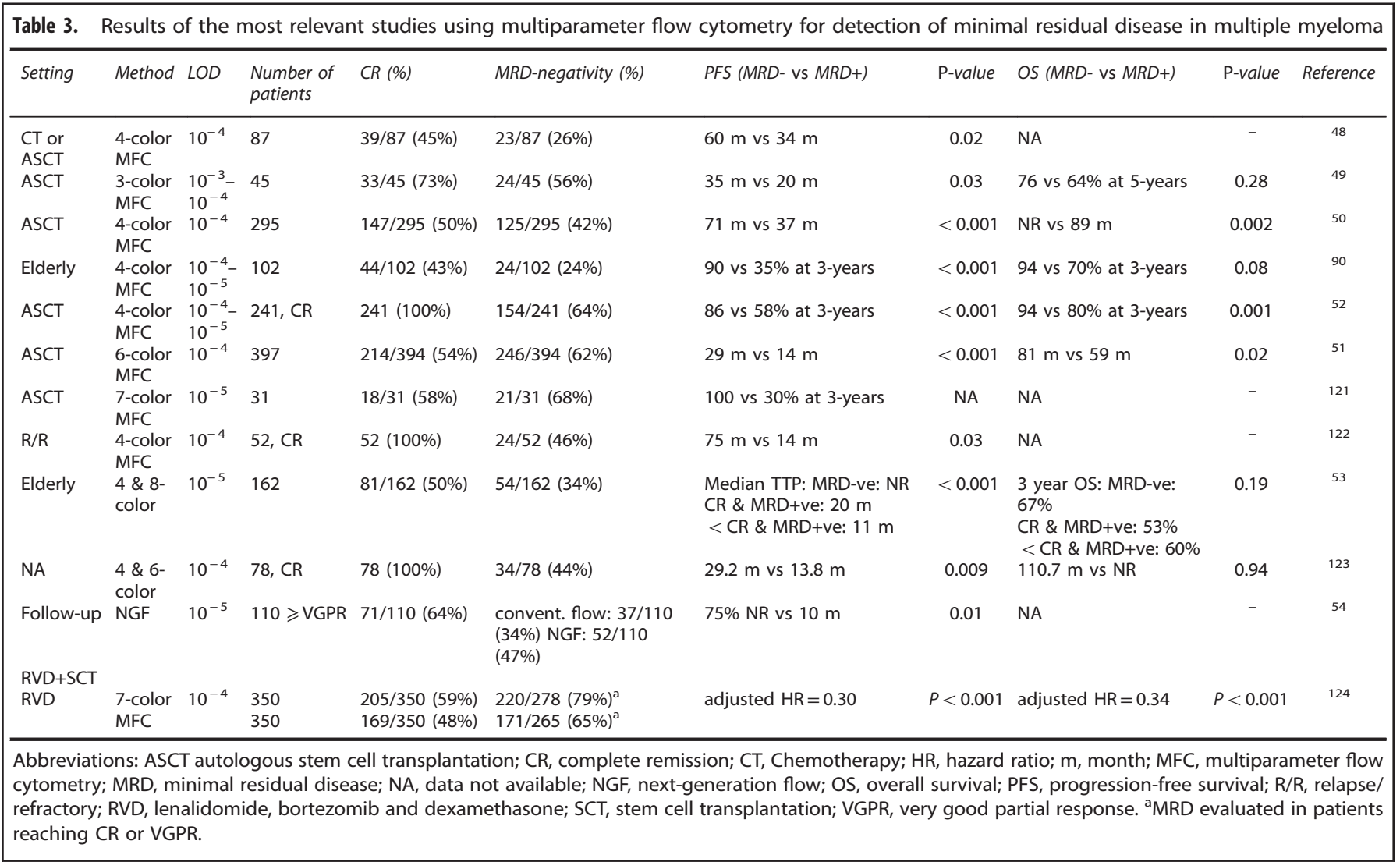

maturation axis of normal PCs, based on these two antigensCD19 and CD81, was proposed. Three BM PC subsets with progressively increased differentiation from CD19+/CD81+ into CD19-/CD81+ and CD19-/CD81-PCs were identified. Authors also demonstrated that MM cells fit into such a model of normal BM PC differentiation and revealed that 59\% of 225 NDMM patients had fully differentiated (CD19-CD81-) clones, 38\% intermediatedifferentiated (CD19-CD81+), and 3\% less-differentiated (CD19 $+\mathrm{CD} 81+$ ) clones. The latter patients had a dismal outcome, and PC differentiation emerged as an independent prognostic marker for PFS and OS. ${ }^{18}$ The prognostic impact of other frequently used markers such as CD20, CD45, CD56 or CD200 is not strong enough to consider them to be independent prognostic markers. ${ }^{22,43}$

The assessment of PC ploidy and proliferation have been long shown to provide prognostic information in $\mathrm{MM}^{4}{ }^{44,45}$ However, it should be noted that while the detection of both nonhyperdiploid DNA content and $\geqslant 1 \%$ PCs in S-phase are of independent prognostic value for OS in newly diagnosed MM patients, treatment with bortezomib-based regimens might abrogate the inferior OS of patients with $\geqslant 1 \%$ PCs in S-phase. ${ }^{46}$ Thus, the prognostic value of MFC-based DNA studies should be revisited in the era of modern treatment strategies.

Role of MFC in response assessment

Traditional response criteria in $\mathrm{MM}$ have been based on the evaluation of serum and urine monoclonal protein concentrations by electrophoresis or immunofixation as a surrogate for tumor burden. ${ }^{47}$ The original definition of complete response (CR) required $<5 \%$ of $\mathrm{PCs}$ in the $\mathrm{BM}$, irrespective of their clonal nature, together with negative immunofixation and disappearance of any soft tissue plasmocytomas. ${ }^{48}$ This definition was further refined to stringent complete response $(s C R)$ by adding the normalization of the serum free light chain (sFLC) ratio and the absence of clonal PCs in BM assessed by IHC. ${ }^{49}$ Nowadays, there is a direct relationship between the depth of the response, particularly CR, and prolonged PFS and OS. This has been confirmed amongst NDMM transplant-eligible as well as elderly patients and also in relapsed/refractory patients. ${ }^{50-52}$ This concept of 'the deeper the response, the longer the survival' is valid for the vast majority of MM patients with the exception of specific molecular subgroups or those with an MGUS-like phenotypic profile. ${ }^{30,53}$ The recent progress in effective treatment strategies for MM was translated in considerably better outcomes with practically $100 \%$ of patients responding to treatment and $>50 \%$ reaching $\mathrm{CR}$. These advances created an unmet need to implement highly sensitive techniques able to determine the presence of very low numbers of clonal PCs within the BM- that is, minimal residual disease (MRD) (Table 3 ). In the most recent International Myeloma Working Group (IMWG) consensus guidelines for response assessment, new MRD criteria were introduced and an MRD-negative status assessed by next-generation flow (NGF) cytometry was included. ${ }^{52}$

The concept of MFC-based monitoring of MRD and its prognostic value was introduced in 2002 by Spanish and UK groups. ${ }^{54,55}$ Paiva et al. demonstrated in 295 uniformly treated NDMM patients receiving HDT/ASCT that MRD-negativity at day +100 after ASCT translated to significantly prolonged PFS (PFS; median 71 vs 37 months, $P<0.001$ ) and OS (OS; median not reached vs 89 months, $P=0.002) .^{56}$ Similarly, Rawstron et al. reported that in 397 patients from the UK MRC Myeloma IX trial, MRD negativity at day +100 after ASCT is highly predictive for favorable outcomes. ${ }^{57}$ Interestingly, the combined evaluation of baseline cytogenetics/FISH and flow MRD evaluation at day +100 after ASCT provides powerful risk stratification and identifies a subgroup of patients with dismal outcomes of OS of only 2 years 
a
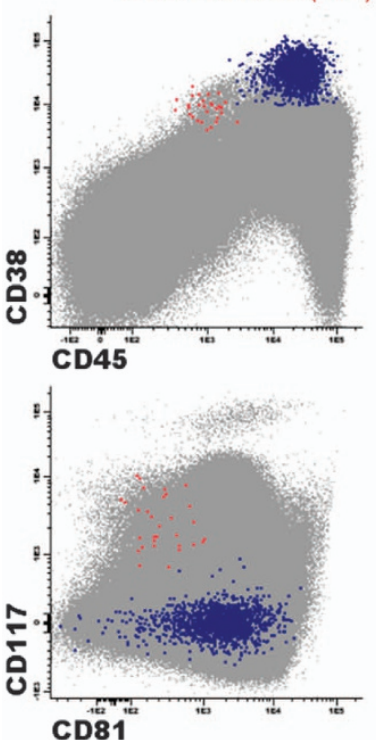

b
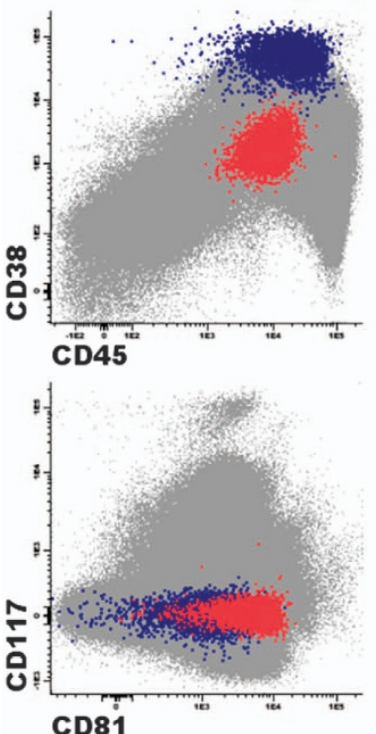
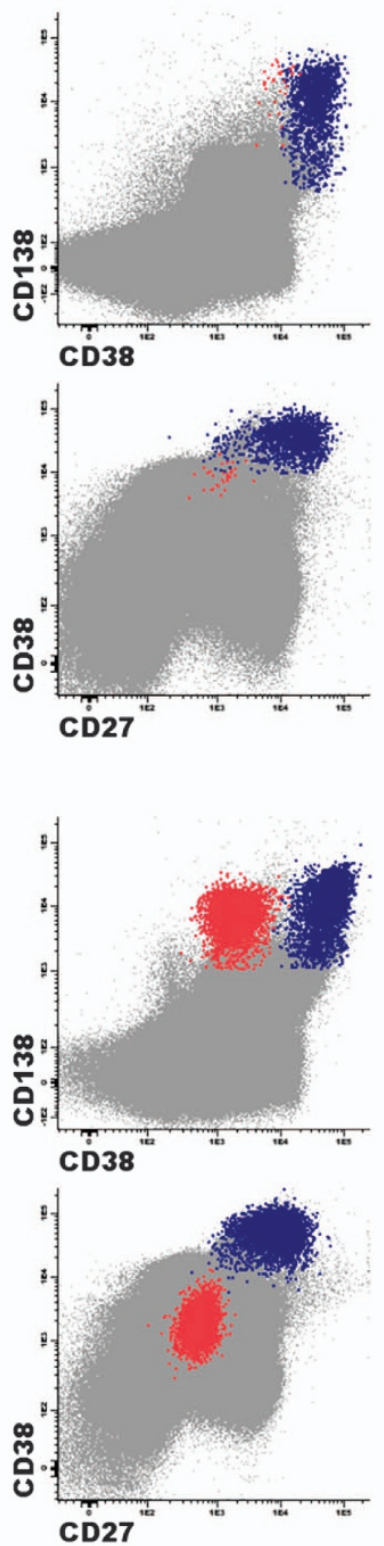
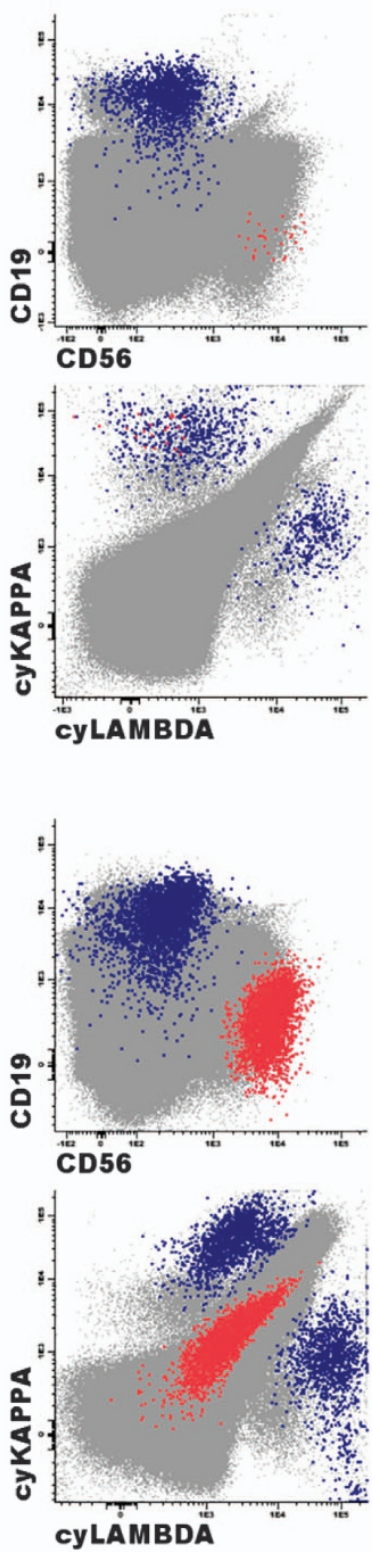

Figure 2. Example of MRD analysis in MM using next generation flow approach and Infinicyt software (Cytognos). (a) Bone marrow PC compartment represents $0.04 \%$ of total nucleated cells including $98.5 \%$ of normal PCs (blue) and $1.5 \%$ of aberrant PCs (red). These aberrant plasma cells represent $0.0004 \%$ of total nucleated cells translating in MRD positive result reaching the sensitivity of $10^{-6}$. The typical aberrant phenotype: CD45-/CD38 $8^{\mathrm{dim}} / \mathrm{CD} 19^{-} / \mathrm{CD} 56^{+} / \mathrm{CD} 27^{-} / \mathrm{CD} 81^{-} / \mathrm{CD} 117^{+} / \mathrm{cyKappa}^{+}$. (b) NGF is optimal tool also for follow-up of patients with nonsecretory multiple myeloma. Bone marrow PC compartment represents $0.16 \%$ of total nucleated cells including $50 \%$ of normal PCs (blue) and $50 \%$ of aberrant PCs (red). Aberrant PCs in this case have rare immunophenotype with CD38- and lack of cytoplasmic staining of kappa or lambda light chains: $\mathrm{CD}_{4}^{+} / \mathrm{CD} 38^{-} / \mathrm{CD}^{-} 9^{-} / \mathrm{CD} 6^{+} / \mathrm{CD}_{2} 7^{-} / \mathrm{CD} 81^{+} / \mathrm{CD}_{117^{-}} / \mathrm{cyKappa}^{-} / \mathrm{cyLambda}^{-}$.

(those with high-risk FISH and MRD positivity). ${ }^{58}$ These studies were performed using 4- and 6-color (the first generation) MRD methods reaching sensitivity of $10^{-4}$ (ability to identify 1 PC in 10000 cells, that is $0.01 \%)$. On the basis of the second-generation flow MRD methods mostly defined by the usage of 8 colors and interrogation of a higher numbers of cells, Paiva et al. showed that the MRD status is one of the most important and independent prognostic factors also in elderly transplant-ineligible patients $(n=162)$. The sensitivity of this method reached $10^{-5}$ (ability to identify 1 PC in 100000 cells, that is, $0.001 \%$ ). This study also showed that it is important to reach the sensitivity of $10^{-5}$ as the patients being MRD positive, even at very low levels below $10^{-4}$, had significantly worse outcomes. ${ }^{59}$ A highly sensitive and fully standardized approach called NGF for MRD detection in MM was implemented by the EuroFlow Consortium recently. Optimized two 8-color tube panels with an established bulk-lysis procedure allow the acquisition of $\geqslant 10^{7}$ cells/sample reaching sensitivity close to $10^{-6}$ (with the limit of detection being 20 clonal PCs among $10^{7}$ evaluated BM cells, that is, $0.0002 \%$ and limit of quantification 50 clonal PCs among $10^{7} \mathrm{BM}$ cells) ${ }^{23}$ Figure 2. Moreover, NGF MRD is applicable to virtually all patients ( $\geqslant 98 \%$ ) and incorporates a quality check of patient BM sample via simultaneous identification of a significant decrease in the non-PC BM population (such as CD117 $7^{+++}$mast cells, nucleated red cells, $117^{+}$myeloid precursors or $\mathrm{CD}_{19^{+}} \mathrm{CD}_{4} 5^{\mathrm{lo}} \mathrm{CD} 38^{+} \mathrm{B}$-cell precursors). This information is crucial to recognize potentially hemodiluted BM aspirates that may lead to false-negative results. ${ }^{23,60}$ The exact preparation procedures, staining, acquisition 

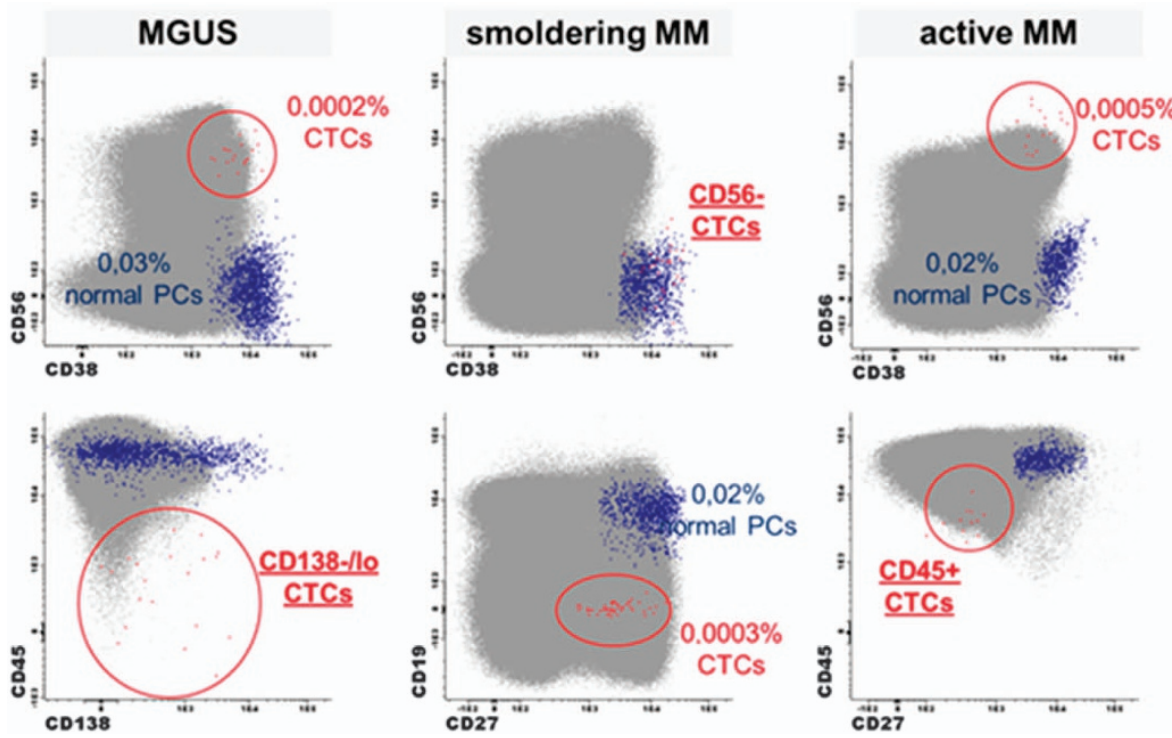

Figure 3. Next-generation flow approach used for identification of CTCS in MGUS, smoldering MM and active MM patients.

and reporting of flow MRD are described in detail in recently published guidelines. ${ }^{16,61}$ Flow MRD represents a fast, highly sensitive, standardized, cost-effective and widely available technique for MRD evaluation in MM and is likely to soon be implemented in routine clinical practice as one of the most important clinical endpoints and sensitive readouts of treatment efficacy.

Other alternative to MFC-based method of MRD evaluation represent molecular techniques, mainly ASO-PCR (allele-specific oligonucleotide PCR) and NGS (next-generation sequencing). Both methods reach high levels of sensitivity (down to $10^{-5}-10^{-6}$ ) and do not require immediate sample processing in contrary to MFC method (sample should be processed within 36-48 h after BM harvest). On the other hand, these methods have some disadvantages: (i) lower applicability (ASO-PCR 60-70\%, NGS $90 \%$ ), (ii) requirement of diagnostic sample to identify patientspecific clonotypic sequences, (iii) higher financial costs and (iv) methodologically complex and laborious methods difficult to implement in routine clinical practice. ${ }^{62-64}$

\section{CIRCULATING PLASMA CELLS}

Long-living BM PCs do not circulate under physiological conditions in $\mathrm{PB}$, but in patients with certain monoclonal gammopathies (MG) tumor cells can egress from BM into PB as circulating tumor cells (CTCs). Accordingly, the presence of CTCs was documented not only in symptomatic MM, but also in SMM and MGUS. ${ }^{65,66}$ Paiva et al. ${ }^{67}$ demonstrated that in MM the number of CTCs fluctuates throughout the day, following a circadian rhythm similar to $\mathrm{CD}_{3} 4^{+}$cells, suggesting that CTCs may egress to PB to colonize other sites during the patients' resting period.

The detection of CTCs in NDMM patients by conventional morphology is low ( $20 \%$ of all cases). ${ }^{68}$ By using more sensitive MFC (Figure 3), CTCs are detected in approximately $70-87 \%$ of all NDMM patients ${ }^{65,69,70}$ and up to $60 \%$ of MGUS patients. ${ }^{71}$ The number of CTCs is an independent prognostic factor in NDMM patients as well as in $\mathrm{AL}$ amyloidosis, and their presence is associated with shorter survival. ${ }^{66,72-74}$ CTCs are associated with an increased risk of malignant transformation in $\mathrm{MGUS}^{72}$ and $\mathrm{SMM}^{75,76}$ and they are also a negative prognostic factor in RRMM. ${ }^{77}$ It is expected that particularly in SMM, MFC could become a convenient method (that is, non-invasive) to identify patients with high-risk of progression to
MM before they develop end-organ damage. ${ }^{76}$ CTC FACS could also be used as a minimally-invasive method to interrogate patients' genomic landscape over time. ${ }^{78}$

From a biological standpoint, in comparison to BM PCs, CTCs show down-regulation of some surface markers such as several integrins (CD11a/CD11c/CD29/CD49d/CD49e), adhesion molecules (CD33/CD56/CD117/CD138), and activation molecules (CD28/CD38/ CD81) ${ }^{67}$ However, the cause and mechanism of PC egression from $\mathrm{BM}$ remains poorly understood, as one of the hallmarks of aPCs in early stages of the disease is their dependence on the BM microenvironment. Possible reasons for their migration/expansion may include changes in angiogenesis and the subsequent increase in their proliferative rate, higher incidences of genetic abnormalities or changes in the expression profile of adhesion molecules. ${ }^{67,79,80}$ An important question remains unanswered: is the presence of CTCs linked to the natural development of the disease or does it identify a separate biological subgroup of patients? ${ }^{80-82}$ It was shown that CTCs are mostly quiescent, but they could have a higher clonogenic potential to their paired BM counterparts. This fact could explain their potential ability of dissemination. In such cases, CTCs would represent a unique subpopulation of $\mathrm{BM}$ clonal $\mathrm{PCs}{ }^{67}$ Recently, Bretones et al. compared exomes of FASC sorted BM PCs, CTCs and PCs from extramedullary (EM) tissues in $6 \mathrm{MM}$ patients with EM disease and demonstrated the presence of systematic inter-tissue heterogeneity (though not for targetable mutations). CTCs displayed the highest frequency of shared mutations with the two other clones and the lowest number of private mutations, suggesting that while CTCs may bridge BM and EM myeloma, there is continuous genomic evolution once different clones have seeded in their respective niches. ${ }^{83}$

\section{SOLITARY PLASMOCYTOMA}

Solitary plasmocytomas (SPs) are rare PC dyscrasias $(<5 \%)$ that are characterized by the presence of bone (solitary bone plasmocytoma-SBP) or extramedullary soft tissue (extramedullary plasmocytoma-EMP) infiltrates of tumor PCs in the absence of any clinical, laboratory and radiologic features of MM. ${ }^{84,85}$ Local radiotherapy, with or without surgical excision, is the recommended treatment of choice for these patients, and achieves high OS rates. Patients with SBP may progress to $\mathrm{MM}$ at a rate of approximately $40-50 \%$, with lower rates of progression for 
EMP. ${ }^{85,86}$ According to the 2014 IMWG criteria, SPs were divided into 2 entities: with or without minimal BM involvement based on the evaluation of the presence of tumor PCs by MFC, Table 1. In fact, the presence of tumor PCS in patients with SP has become the most important prognostic marker defining the risk of progression. Paiva et al. have detected tumor PCs in 49\% (17/35) of SBP patients and in 38\% (11/29) of EMP patients. Seventy-one percent of flow-positive vs only $8 \%$ of flow-negative SBP patients evolved to MM (hazard ratio, 17.4; $P<0.001$ ). No significant differences were observed among EMP cases. Almost identical results were published by a UK group ${ }^{84}$ enhancing the importance of MFC for the sub-classification of patients with SP and leading to its new classification as noted above.

\section{AL AMYLOIDOSIS}

Immunoglobulin light-chain amyloidosis (AL amyloidosis) is a rare PCD with an incidence of 10 patients per million cases per year but represents the most common of systemic amyloidoses. ${ }^{87}$ This often fatal disorder is characterized by the presence of a usually small indolent clone of BM PCs that produce misfolded monoclonal light chains of $\mathrm{K}$ or most predominantly $\lambda$ isotype formatting insoluble fibrils causing damage to vital organs, Table $1{ }^{88}$ In AL, MFC can be useful to confirm the presence of underlying tumor PCs responsible for the deposition of the amyloid light chains in tissue biopsies. This underlying tumor PC clone is present and revealed by MFC in virtually all $A L$ patients. ${ }^{89,90}$ There are only few MFC studies focusing on its prognostic value due to the rarity of this disease. Quantification of the BM PC compartment by MFC was found to be a significant prognostic factor for OS ( $<1$ vs $>1 \%$ BMPC cutoff; 2-year OS rates of 90 vs $44 \%, P=0.02$ ) in the cohort of 35 newly diagnosed $A L$ patients. Moreover, detecting persistent nPCs at diagnosis identified a subgroup of patients with prolonged OS (cut off $>5$ vs $<5 \%$ of nPCs/BMPC, 2-year rates of 88 vs $37 \%, P=0.01$ ). In these series, $49 \%$ (17/35) of AL patients had $>5 \%$ of $n P C s / B M P C$ at diagnosis. ${ }^{91}$ More recently, a very similar study was published by the Mayo Clinic group ( $n=173$ ) confirming some of the above mentioned results using a different cutoff for quantification of BM PCs (2.5\%). ${ }^{92}$

\section{WALDENSTRÖM MACROGLOBULINEMIA}

Waldenström macroglobulinemia (WM) was originally described by Jan Gösta Waldenström in $1944 .{ }^{93,94}$ This disease is defined as a lymphoplasmacytic lymphoma associated with the monoclonal immunoglobulin IgM and BM infiltration by small IgM-producing clonal B-lymphocytes that may exhibit PC differentiation. ${ }^{95}$ An incidence of 4 cases per million persons per year ranks this disease amongst rare disorders. ${ }^{93}$ The clinical presentation of patients with WM can be highly variable as the signs and symptoms are not only due to the infiltration of BM or lymphoid organs (anemia, hepatosplenomegaly and so on), but also due to the specific physiochemical and immunological properties of monoclonal lgM (peripheral neuropathy, hyperviscosity and so on). ${ }^{96}$ Similarly to $\mathrm{MM}$, it is supposed that virtually all cases of WM have gone through the benign stages of IgM MGUS and smoldering WM (SWM) before developing clinical symptoms. The hallmark of these three entities is the presence of the monoclonal $\operatorname{lgM}$ protein. The difference between IgM MGUS and smoldering WM is in the BM infiltration by B-lymphocytes (with a cutoff of $10 \%$ defined by morphology). Smoldering WM, in contrast to symptomatic WM, lacks any diseaseassociated clinical symptoms, thus not requiring any treatment. ${ }^{95,97}$ Advances in understanding the molecular pathogenesis of WM have been paved by the discovery of a recurrent somatic mutation in MYD88 $265 \mathrm{P}$ that is present in more than $90 \%$ of symptomatic WM patients, but also in at least half of IgM MGUS patients suggesting its role as an early oncogenic event. ${ }^{98,99}$ The most plausible normal counterpart of the WM clonal B-cell seems to be a
CD22 $2^{\text {low }+} / \mathrm{CD} 25^{+}$memory B-cell as the cell of tumor origin, ${ }^{97}$ even though this question has still not been fully answered. ${ }^{100}$

MFC plays a significant role in the differential diagnostic workup. It is particularly useful to distinguish WM from other B-cell lymphoproliferative disorders as well as from related lgM monoclonal gammopathies (that is, IgM MGUS, IgM myeloma) based on the specific immunophenotype of WM B-cells and PCs. ${ }^{96}$ The co-existence of a clonal B-cell population and the same lightchain-isotype clonal plasma cell population within the BM compartment is usually accompanied by an increased number of mast cells, thus representing typical findings. ${ }^{101}$ The most common immunophenotype of WM clonal B-cells can be described as follows: $\mathrm{CD} 19^{+} / \mathrm{CD} 22^{\text {low }+} / \mathrm{CD} 23^{-} / \mathrm{CD} 25^{+} / \mathrm{CD} 27^{+}$ $/ \mathrm{SmlgM}^{+}$. In more detail, clonal B-cells systematically show $\mathrm{SmlgM}^{+}$expression, with homogenously expressed CD22 $2^{\text {low }+}$ ( $81 \%$ of cases) and $\mathrm{CD}^{+} 5^{+}$(89\% of cases). CD79b and CD81 are positive in all cases, whereas a heterogeneous bimodal pattern of expression can be observed for CD27 (51\% of cases), CD38 (50\%) and CD200 (62\%). CD305 (LAIR1) is not expressed in up to $69 \%$ of cases in contrast to its bimodal heterogeneous expression on normal B-cells. The absence of the expression of CD5, CD10, CD11c and CD103 (in 95\%, 10096 and 100\% of cases, respectively) is in contrast with most other mature lymphoid malignancies (chronic lymphocytic leukemia, mantle cell lymphoma, follicular lymphoma and hairy cell leukemia) except of marginal zone lymphoma (MZL), thus helping in their distinction. The most useful markers to discriminate between WM and MZL, that possess the overlapping phenotype in some cases, were SmlgM and CD79b, both over-expressed in WM, and CD305 upregulated in MZL. ${ }^{97,102}$

The antigenic profile of clonal PCs in WM resembles more that of normal PCs and clearly differs from that of MM patients

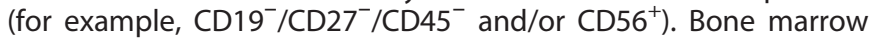
PCs from IgM MGUS to symptomatic WM patients show a progressively increased frequency of $\mathrm{CD} 19^{+} / \mathrm{CD} 20^{+} / \mathrm{CD} 45^{+}$and $\mathrm{SmlgM}^{+}$cells, together with a complete loss of CD56 reactivity. This suggests that the PC compartment is enriched in more immature clonal PCs with the plasmablastic phenotype. ${ }^{103}$ The different antigenic profile of clonal PCs can have a valuable input to distinguish WM from IgM MM, together with the MYD88 mutation status (not present in $\lg M \mathrm{MM}$ ) and the presence of $\mathrm{t}(11$; 14) (does not occur in WM but with a high incidence in IgM MM). ${ }^{93,104,105}$

Flow cytometry may be a useful tool in the discrimination between lgM-related disorders. The thresholds of BM B-cell infiltration $(>10 \%)$ and the degree of B-cell clonality $(100 \%)$ are highly specific to exclude the diagnosis of IgM-MGUS, but not otherwise to identify WM patients. However, flow cytometry can also serve as a valuable prognostic tool in patients with smoldering and symptomatic WM. Patients with smoldering WM who have more than $10 \%$ of BM B-cell infiltration and who show full light-chain restriction of the B-cell compartment are at a higher risk of progression to symptomatic disease (median TTP of 26 vs 145 months, $P \leqslant 0.001)$. Similarly, patients with symptomatic WM and with $100 \%$ of light chain restricted B-cells show inferior survival vs those who maintain some polyclonal B-cells (median OS of 44 vs 78 months, $P=0.001$ ). To note, full light chain restriction of the PC compartment has no effect on both TTP and $\mathrm{OS}$ in smoldering and symptomatic WM patients, respectively. ${ }^{102}$

Finally, the role of MFC was also investigated during the response assessment. García-Sanz et al. ${ }^{106}$ described in 42 WM patients that post-treatment BM residual disease status $>5 \%$ of monoclonal B-cells was highly predictive of short PFS and OS, independently on hematological response. With the availability of more effective therapies for WM, it will be critical to combine sensitive and comprehensive monitoring of clonality in both B-cells and PCs together with the evaluation of serum M-protein, since the complete eradication of only clonal B-cells but not PCs 
(for example, through anti-CD20 immunochemotherapy) may translate into a favorable outcome despite sub-optimal response according to current criteria (that is, persistent M-protein).

\section{CONCLUSION}

MFC immunophenotyping has become routinely used in the management of patients with PC dyscrasias. MFC plays a significant role during the differential diagnostic work-up, when this technique can provide relatively fast and conclusive results, thus helping to distinguish between malignant and reactive conditions as well as classifying different monoclonal gammopathies and other lymphoproliferative disorders. Flow cytometry can also be useful in predicting outcomes not only in MGUS/SMM/MM, but also in patients with SWM/WM, AL and SP. The obtained information could be particularly beneficial in maintaining a closer surveillance of patients at a higher risk of progression and in identifying the subgroup of patients with exceptionally favorable outcomes. Flow-based MRD monitoring in MM, particularly after the implementation of NGF, represents a fast, highly sensitive, standardized, cost-effective and widely available technique. The importance of defining the MRD status is indisputable in MM patients and flow MRD is progressively being implemented in routine clinical practice as one of the most relevant treatment end-points. Immunophenotyping has greatly contributed also in the research of monoclonal gammopathies and may be of significant importance in the upcoming era of immunotherapy, especially in defining and monitoring therapeutic targets such as CD38, SLAMF7, PD-L1, BCMA and many others that are yet to be discovered. ${ }^{107,108}$

\section{CONFLICT OF INTEREST}

The authors declare no conflict of interest.

\section{ACKNOWLEDGEMENTS}

We give special thanks to Shira Timilsina, MD for English language editing. This work was supported by the MH CZ_DRO-FNOs/2017 and Ministry of Health (17-30089A); by the Institutional Development Plan of University of Ostrava (IRP201550), by SGS18/ PrF/2017-2018 and by 'Strengthening international cooperation in science, research and education, projet ID: 01211/2016/RRC'. It was also supported by the International Myeloma Foundation Black Swan Research Initiative and the European Research Council (ERC) 2015 Starting Grant (MYELOMA-NEXT).

\section{AUTHOR CONTRIBUTIONS}

TJ-wrote the manuscript, concept, coordination. RB-wrote the part about CTCS and PCL. MZ-took part in the preparation of the manuscript. LB-took part in the preparation of the manuscript. MS - took part in the preparation of the manuscript, overall proofread. TS-overall proofread. BP-concept, overall proofread, work coordination. $\mathrm{RH}$-work coordination, overall proofread.

\section{REFERENCES}

1 Castillo JJ. Plasma cell disorders. Prim Care 2016; 43: 677-691.

2 Sant M, Allemani C, Tereanu C, Angelis RD, Capocaccia R, Visser O et al. Incidence of hematologic malignancies in Europe by morphologic subtype: results of the HAEMACARE project. Blood 2010; 116: 3724-3734.

3 Rajkumar SV, Dimopoulos MA, Palumbo A, Blade J, Merlini G, Mateos M-V et al. International Myeloma Working Group updated criteria for the diagnosis of multiple myeloma. Lancet Oncol 2014; 15: e538-e548.

4 Kyle RA, Therneau TM, Rajkumar SV, Larson DR, Plevak MF, Offord JR et al. Prevalence of monoclonal gammopathy of undetermined significance. $N$ Engl J Med 2006; 354: 1362-1369.

5 Bladé J. Clinical practice. Monoclonal gammopathy of undetermined significance. N Engl J Med 2006; 355: 2765-2770.

6 Kyle RA, Rajkumar SV. Epidemiology of the plasma-cell disorders. Best Pract Res Clin Haematol 2007; 20: 637-664.
7 Kyle RA, Therneau TM, Rajkumar SV, Offord JR, Larson DR, Plevak MF et al. A long-term study of prognosis in monoclonal gammopathy of undetermined significance. N Engl J Med 2002; 346: 564-569.

8 Kyle RA, Remstein ED, Therneau TM, Dispenzieri A, Kurtin PJ, Hodnefield JM et al. Clinical course and prognosis of smoldering (asymptomatic) multiple myeloma. N Engl J Med 2007; 356: 2582-2590.

9 Kaleem Z, Crawford E, Pathan MH, Jasper L, Covinsky MA, Johnson LR et al. Flow cytometric analysis of acute leukemias. Diagnostic utility and critical analysis of data. Arch Pathol Lab Med 2003; 127: 42-48.

10 Braylan RC. Impact of flow cytometry on the diagnosis and characterization of lymphomas, chronic lymphoproliferative disorders and plasma cell neoplasias. Cytom Part J Int Soc Anal Cytol 2004; 58: 57-61.

11 Kwok M, Rawstron AC, Varghese A, Evans PAS, O'Connor SJM, Doughty C et al. Minimal residual disease is an independent predictor for 10-year survival in CLL. Blood 2016; 128: 2770-2773.

12 Theunissen P, Mejstrikova E, Sedek L, van der Sluijs-Gelling AJ, Gaipa G, Bartels M et al. Standardized flow cytometry for highly sensitive MRD measurements in B-cell acute lymphoblastic leukemia. Blood 2016; 129: 347-357.

13 Grimwade D, Freeman SD. Defining minimal residual disease in acute myeloid leukemia: which platforms are ready for 'prime time'? Blood 2014; 124: 3345-3355.

14 Caraux A, Klein B, Paiva B, Bret C, Schmitz A, Fuhler GM et al. Circulating human B and plasma cells. Age-associated changes in counts and detailed characterization of circulating normal CD138- and CD138+ plasma cells. Haematologica 2010; 95: 1016-1020.

15 Jelinek T, Hajek R. Monoclonal antibodies - A new era in the treatment of multiple myeloma. Blood Rev 2016; 30: 101-110.

16 Arroz M, Came N, Lin P, Chen W, Yuan C, Lagoo A et al. Consensus guidelines on plasma cell myeloma minimal residual disease analysis and reporting. Cytometry B Clin Cytom 2016; 90: 31-39.

17 Flores-Montero J, de Tute R, Paiva B, Perez JJ, Böttcher S, Wind H et al. Immunophenotype of normal vs. myeloma plasma cells: toward antibody panel specifications for MRD detection in multiple myeloma. Cytometry B Clin Cytom 2016; 90: 61-72.

18 Paiva B, Puig N, Cedena MT, de Jong BG, Ruiz Y, Rapado I et al. Differentiation stage of myeloma plasma cells: biological and clinical significance. Leukemia 2017; 31: 382-392.

19 Ocqueteau M, Orfao A, Almeida J, Bladé J, González M, García-Sanz R et al. Immunophenotypic characterization of plasma cells from monoclonal gammopathy of undetermined significance patients. Implications for the differential diagnosis between MGUS and multiple myeloma. Am J Pathol 1998; 152: 1655-1665.

20 Paiva B, Merino J, San Miguel JF. Utility of flow cytometry studies in the management of patients with multiple myeloma. Curr Opin Oncol 2016; 28: 511-517.

21 Olteanu H, Harrington AM, Hari P, Kroft SH. CD200 expression in plasma cell myeloma. Br J Haematol 2011; 153: 408-411.

22 Olteanu $\mathrm{H}$. Role of flow cytometry in the diagnosis and prognosis of plasma cell myeloma. Surg Pathol Clin 2016; 9: 101-116.

23 Flores-Montero J, Sanoja-Flores L, Paiva B, Puig N, García-Sánchez O, Böttcher S et al. Next Generation Flow for highly sensitive and standardized detection of minimal residual disease in multiple myeloma. Leukemia 2017; 31: 2094-2103.

24 Nadav L, Katz B-Z, Baron S, Yossipov L, Polliack A, Deutsch V et al. Diverse niches within multiple myeloma bone marrow aspirates affect plasma cell enumeration. Br J Haematol 2006; 133: 530-532.

25 Rawstron AC, Orfao A, Beksac M, Bezdickova L, Brooimans RA, Bumbea $\mathrm{H}$ et al. Report of the European Myeloma Network on multiparametric flow cytometry in multiple myeloma and related disorders. Haematologica 2008; 93: 431-438.

26 Seegmiller AC, Xu Y, McKenna RW, Karandikar NJ. Immunophenotypic differentiation between neoplastic plasma cells in mature B-cell lymphoma vs plasma cell myeloma. Am J Clin Pathol 2007; 127: 176-181.

27 Olteanu H, Wang H-Y, Chen W, McKenna RW, Karandikar NJ. Immunophenotypic studies of monoclonal gammopathy of undetermined significance. BMC Clin Pathol 2008; 8: 13.

28 Paiva B, Almeida J, Pérez-Andrés M, Mateo G, López A, Rasillo A et al. Utility of flow cytometry immunophenotyping in multiple myeloma and other clonal plasma cell-related disorders. Cytometry B Clin Cytom 2010; 78: 239-252.

29 Pérez-Persona E, Vidriales M-B, Mateo G, García-Sanz R, Mateos M-V, de Coca AG et al. New criteria to identify risk of progression in monoclonal gammopathy of uncertain significance and smoldering multiple myeloma based on multiparameter flow cytometry analysis of bone marrow plasma cells. Blood 2007; 110: 2586-2592.

30 Paiva B, Vídriales M-B, Rosiñol L, Martínez-López J, Mateos M-V, Ocio EM et al. A multiparameter flow cytometry immunophenotypic algorithm for the identification of newly diagnosed symptomatic myeloma with an MGUS-like signature and long-term disease control. Leukemia 2013; 27: 2056-2061. 
31 Greipp PR, Miguel JS, Durie BGM, Crowley JJ, Barlogie B, Bladé J et al. International Staging System for Multiple Myeloma. J Clin Oncol 2005; 23: 3412-3420.

32 Palumbo A, Avet-Loiseau H, Oliva S, Lokhorst HM, Goldschmidt H, Rosinol L et al. Revised international staging system for multiple myeloma: A Report From International Myeloma Working Group. J Clin Oncol Off J Am Soc Clin Oncol 2015; 33: 2863-2869.

33 Avet-Loiseau H, Durie BGM, Cavo M, Attal M, Gutierrez N, Haessler J et al. Combining fluorescent in situ hybridization data with ISS staging improves risk assessment in myeloma: an International Myeloma Working Group collaborative project. Leukemia 2013; 27: 711-717.

34 Pérez-Persona E, Mateo G, García-Sanz R, Mateos M-V, de Las Heras N, de Coca AG et al. Risk of progression in smouldering myeloma and monoclonal gammopathies of unknown significance: comparative analysis of the evolution of monoclonal component and multiparameter flow cytometry of bone marrow plasma cells. Br J Haematol 2010; 148: 110-114.

35 Paiva B, Johnson SK, Mateos M-V, Alapat DV, Puig N, Hernandez M-T et al. Automated multiparameter flow cytometry (MFC) immunophenotyping for reproducible identification of high risk smoldering multiple myeloma (SMM). Blood 2016; 128: 373-373.

36 Paiva B, Vidriales M-B, Mateo G, Pérez JJ, Montalbán MA, Sureda A et al. The persistence of immunophenotypically normal residual bone marrow plasma cells at diagnosis identifies a good prognostic subgroup of symptomatic multiple myeloma patients. Blood 2009; 114: 4369-4372.

37 Lahuerta J-J, Paiva B, Vidriales M-B, Cordón L, Cedena M-T, Puig N et al. Depth of response in multiple myeloma: a pooled analysis of three PETHEMA/GEM Clinical Trials. J Clin Oncol 2017; 35: 2900-2910.

38 Edling CE, Hallberg B. c-Kit-a hematopoietic cell essential receptor tyrosine kinase. Int J Biochem Cell Biol 2007; 39: 1995-1998.

39 Mateo G, Montalbán MA, Vidriales M-B, Lahuerta JJ, Mateos MV, Gutiérrez N et al. Prognostic value of immunophenotyping in multiple myeloma: a study by the PETHEMA/GEM cooperative study groups on patients uniformly treated with high-dose therapy. J Clin Oncol Off J Am Soc Clin Oncol 2008; 26: 2737-2744.

40 Schmidt-Hieber $M$, Pérez-Andrés $M$, Paiva B, Flores-Montero J, Perez J, Gutierrez NC et al. CD117 expression in gammopathies is associated with an altered maturation of the myeloid and lymphoid hematopoietic cell compartments and favorable disease features. Haematologica 2011; 96: 328-332.

41 Murray ME, Gavile CM, Nair JR, Koorella C, Carlson LM, Buac D et al. CD28mediated pro-survival signaling induces chemotherapeutic resistance in multiple myeloma. Blood 2014; 123: 3770-3779.

42 Paiva B, Gutiérrez N-C, Chen X, Vídriales M-B, Montalbán M-Á, Rosiñol L et al. Clinical significance of CD81 expression by clonal plasma cells in high-risk smoldering and symptomatic multiple myeloma patients. Leukemia 2012; 26: 1862-1869.

43 Paiva B, Puig N, Arana P, Cedena T, Cordon L, Vidriales MB et al. Prognostic value of antigen expression in multiple myeloma (MM): a large GEM/Pethema Study based in four consecutive clinical trials. Blood 2015; 126: 19-19.

44 San Miguel JF, García-Sanz R, González M, Orfão A. DNA cell content studies in multiple myeloma. Leuk Lymphoma 1996; 23: 33-41.

45 García-Sanz R, Orfão A, González M, Moro MJ, Hernández JM, Ortega F et al. Prognostic implications of DNA aneuploidy in 156 untreated multiple myeloma patients. Castelano-Leonés (Spain) Cooperative Group for the Study of Monoclonal Gammopathies. Br J Haematol 1995; 90: 106-112.

46 Paiva B, Vídriales M-B, Montalbán M-Á, Pérez JJ, Gutiérrez NC, Rosiñol L et al. Multiparameter flow cytometry evaluation of plasma cell DNA content and proliferation in 595 transplant-eligible patients with myeloma included in the Spanish GEM2000 and GEM2005 < 65y trials. Am J Pathol 2012; 181: 1870-1878.

47 Bladé J, Samson D, Reece D, Apperley J, Björkstrand B, Gahrton G et al. Criteria for evaluating disease response and progression in patients with multiple myeloma treated by high-dose therapy and haemopoietic stem cell transplantation. Myeloma Subcommittee of the EBMT. European Group for Blood and Marrow Transplant. Br J Haematol 1998; 102: 1115-1123.

48 Durie BGM, Harousseau J-L, Miguel JS, Bladé J, Barlogie B, Anderson K et al. International uniform response criteria for multiple myeloma. Leukemia 2006; 20: 1467-1473.

49 Rajkumar SV, Harousseau J-L, Durie B, Anderson KC, Dimopoulos M, Kyle R et al. Consensus recommendations for the uniform reporting of clinical trials: report of the International Myeloma Workshop Consensus Panel 1. Blood 2011; 117: 4691-4695.

50 van de Velde HJK, Liu X, Chen G, Cakana A, Deraedt W, Bayssas M. Complete response correlates with long-term survival and progression-free survival in high-dose therapy in multiple myeloma. Haematologica 2007; 92: 1399-1406.

51 Gay F, Larocca A, Wijermans P, Cavallo F, Rossi D, Schaafsma R et al. Complete response correlates with long-term progression-free and overall survival in elderly myeloma treated with novel agents: analysis of 1175 patients. Blood 2011; 117: 3025-3031.
52 Kumar S, Paiva B, Anderson KC, Durie B, Landgren O, Moreau P et al. International Myeloma Working Group consensus criteria for response and minimal residual disease assessment in multiple myeloma. Lancet Oncol 2016; 17: e328-e346.

53 Barlogie B, Mitchell A, van Rhee F, Epstein J, Morgan GJ, Crowley J. Curing myeloma at last: defining criteria and providing the evidence. Blood 2014; 124: 3043-3051.

54 San Miguel JF, Almeida J, Mateo G, Bladé J, López-Berges C, Caballero D et al. Immunophenotypic evaluation of the plasma cell compartment in multiple myeloma: a tool for comparing the efficacy of different treatment strategies and predicting outcome. Blood 2002; 99: 1853-1856.

55 Rawstron AC, Davies FE, DasGupta R, Ashcroft AJ, Patmore R, Drayson MT et al. Flow cytometric disease monitoring in multiple myeloma: the relationship between normal and neoplastic plasma cells predicts outcome after transplantation. Blood 2002; 100: 3095-3100.

56 Paiva B, Vidriales M-B, Cerveró J, Mateo G, Pérez JJ, Montalbán MA et al. Multiparameter flow cytometric remission is the most relevant prognostic factor for multiple myeloma patients who undergo autologous stem cell transplantation. Blood 2008; 112: 4017-4023.

57 Rawstron AC, Child JA, de Tute RM, Davies FE, Gregory WM, Bell SE et al. Minimal residual disease assessed by multiparameter flow cytometry in multiple myeloma: impact on outcome in the Medical Research Council Myeloma IX Study. J Clin Oncol Off J Am Soc Clin Oncol 2013; 31: 2540-2547.

58 Paiva B, Gutiérrez NC, Rosiñol L, Vídriales M-B, Montalbán M-Á, Martínez-López J et al. High-risk cytogenetics and persistent minimal residual disease by multiparameter flow cytometry predict unsustained complete response after autologous stem cell transplantation in multiple myeloma. Blood 2012; 119: 687-691.

59 Paiva B, Cedena M-T, Puig N, Arana P, Vidriales M-B, Cordon L et al. Minimal residual disease monitoring and immune profiling in multiple myeloma in elderly patients. Blood 2016; 127: 3165-3174.

60 Paiva B, García-Sanz R, San Miguel JF. Multiple Myeloma Minimal Residual Disease. Cancer Treat Res 2016; 169: 103-122.

61 Stetler-Stevenson M, Paiva B, Stoolman L, Lin P, Jorgensen JL, Orfao A et al. Consensus guidelines for myeloma minimal residual disease sample staining and data acquisition. Cytometry B Clin Cytom 2016; 90: 26-30.

62 Martinez-Lopez J, Sanchez-Vega B, Barrio S, Cuenca I, Ruiz-Heredia Y, Alonso R et al. Analytical and clinical validation of a novel in-house deep-sequencing method for minimal residual disease monitoring in a phase II trial for multiple myeloma. Leukemia 2017; 31: 1446-1449.

63 Martinez-Lopez J, Lahuerta JJ, Pepin F, González M, Barrio S, Ayala R et al. Prognostic value of deep sequencing method for minimal residual disease detection in multiple myeloma. Blood 2014; 123: 3073-3079.

64 Puig N, Sarasquete ME, Balanzategui A, Martínez J, Paiva B, García H et al. Critical evaluation of ASO RQ-PCR for minimal residual disease evaluation in multiple myelomaA comparative analysis with flow cytometry. Leukemia 2014; 28: 391-397.

65 Nowakowski GS, Witzig TE, Dingli D, Tracz MJ, Gertz MA, Lacy MQ et al. Circulating plasma cells detected by flow cytometry as a predictor of survival in 302 patients with newly diagnosed multiple myeloma. Blood 2005; 106: 2276-2279.

66 Gonsalves WI, Rajkumar SV, Gupta V, Morice WG, Timm MM, Singh PP et al. Quantification of clonal circulating plasma cells in newly diagnosed multiple myeloma: implications for redefining high-risk myeloma. Leukemia 2014; 28: 2060-2065.

67 Paiva B, Paino T, Sayagues J-M, Garayoa M, San-Segundo L, Martín M et al. Detailed characterization of multiple myeloma circulating tumor cells shows unique phenotypic, cytogenetic, functional, and circadian distribution profile. Blood 2013; 122: 3591-3598.

68 Granell M, Calvo X, Garcia-Guiñón A, Escoda L, Abella E, Martínez CM et al. Prognostic impact of circulating plasma cells in patients with multiple myeloma: implications for plasma cell leukaemia definition. Haematologica 2017; 102: 1099-1104, haematol.2016.158303.

69 Vagnoni D, Travaglini F, Pezzoni V, Ruggieri M, Bigazzi C, Dalsass A et al. Circulating plasma cells in newly diagnosed symptomatic multiple myeloma as a possible prognostic marker for patients with standard-risk cytogenetics. Br J Haematol 2015; 170: 523-531.

70 San Miguel JF, Gutiérrez NC, Mateo G, Orfao A. Conventional diagnostics in multiple myeloma. Eur J Cancer Oxf Engl 1990 2006; 42: 1510-1519.

71 Burgos L, Alignani D, Garces J-J, Ortiz L, Jelinek T, Segura V et al. Non-invasive genetic profiling is highly applicable in multiple myeloma (MM) through characterization of circulating tumor cells (CTCS). Blood 2016; 128: 801-801.

72 Kumar S, Rajkumar SV, Kyle RA, Lacy MQ, Dispenzieri A, Fonseca R et al. Prognostic value of circulating plasma cells in monoclonal gammopathy of undetermined significance. J Clin Oncol 2005; 23: 5668-5674.

73 Dingli D, Nowakowski GS, Dispenzieri A, Lacy MQ, Hayman SR, Rajkumar SV et al. Flow cytometric detection of circulating myeloma cells before transplantation in 
patients with multiple myeloma: a simple risk stratification system. Blood 2006; 107: 3384-3388.

74 Pardanani A, Witzig TE, Schroeder G, McElroy EA, Fonseca R, Dispenzieri A et al. Circulating peripheral blood plasma cells as a prognostic indicator in patients with primary systemic amyloidosis. Blood 2003; 101: 827-830.

75 Bianchi G, Kyle RA, Larson DR, Witzig TE, Kumar S, Dispenzieri A et al. High levels of peripheral blood circulating plasma cells as a specific risk factor for progression of smoldering multiple myeloma. Leukemia 2013; 27: 680-685.

76 Gonsalves WI, Rajkumar SV, Dispenzieri A, Dingli D, Timm MM, Morice WG et al. Quantification of circulating clonal plasma cells via multiparametric flow cytometry identifies patients with smoldering multiple myeloma at high risk of progression. Leukemia 2017; 31: 130-135.

77 Peceliunas V, Janiulioniene A, Matuzeviciene R, Zvirblis T, Griskevicius L. Circulating plasma cells predict the outcome of relapsed or refractory multiple myeloma. Leuk Lymphoma 2012; 53: 641-647.

78 Mishima Y, Paiva B, Shi J, Park J, Manier S, Takagi S et al. The mutational landscape of circulating tumor cells in multiple myeloma. Cell Rep 2017; 19: 218-224.

79 Kumar S, Witzig TE, Greipp PR, Rajkumar SV. Bone marrow angiogenesis and circulating plasma cells in multiple myeloma. Br J Haematol 2003; 122: 272-274.

80 An G, Qin X, Acharya C, Xu Y, Deng S, Shi L et al. Multiple myeloma patients with low proportion of circulating plasma cells had similar survival with primary plasma cell leukemia patients. Ann Hematol 2015; 94: 257-264.

81 Pellat-Deceunynck C, Barillé S, Jego G, Puthier D, Robillard N, Pineau D et al. The absence of CD56 (NCAM) on malignant plasma cells is a hallmark of plasma cell leukemia and of a special subset of multiple myeloma. Leukemia 1998; 12: 1977-1982.

82 Lohr JG, Kim S, Gould J, Knoechel B, Drier Y, Cotton MJ et al. Genetic interrogation of circulating multiple myeloma cells at single-cell resolution. Sci Transl Med 2016; 8: 363ra147.

83 Bretones G, Paiva B, Valdes-Mas R, Alignani D, Garcia M, Burgos L et al. Genomic profiles of bone marrow (BM) clonal plasma cells (PCs) vs circulating tumor cells (CTCS) and Extramedullary (EM) plasmacytomas in multiple myeloma (MM). Blood 2016; 128: 4442-4442.

84 Hill QA, Rawstron AC, de Tute RM, Owen RG. Outcome prediction in plasmacytoma of bone: a risk model utilizing bone marrow flow cytometry and light-chain analysis. Blood 2014; 124: 1296-1299.

85 Dimopoulos MA, Terpos E. Solitary bone plasmacytomas need to flow. Blood 2014; 124: 1209-1210.

86 Katodritou E, Terpos E, Symeonidis AS, Pouli A, Kelaidi C, Kyrtsonis M-C et al. Clinical features, outcome, and prognostic factors for survival and evolution to multiple myeloma of solitary plasmacytomas: a report of the Greek myeloma study group in 97 patients. Am J Hematol 2014; 89: 803-808.

87 Jelinek T, Kryukova E, Kufova Z, Kryukov F, Hajek R. Proteasome inhibitors in $\mathrm{AL}$ amyloidosis: focus on mechanism of action and clinical activity. Hematol Oncol 2016; e-pub ahead of print 20 September 2016; doi:10.1002/hon.2351.

88 Jelinek T, Kufova Z, Hajek R. Immunomodulatory drugs in AL amyloidosis. Crit Rev Oncol Hematol 2016; 99: 249-260.

89 Paiva B, Martinez-Lopez J, Corchete LA, Sanchez-Vega B, Rapado I, Puig N et al. Phenotypic, transcriptomic, and genomic features of clonal plasma cells in lightchain amyloidosis. Blood 2016; 127: 3035-3039.

90 Lisenko K, Schönland SO, Jauch A, Andrulis M, Röcken C, Ho AD et al. Flow cytometry-based characterization of underlying clonal $B$ and plasma cells in patients with light chain amyloidosis. Cancer Med 2016; 5: 1464-1472.

91 Paiva B, Vídriales M-B, Pérez JJ, López-Berges M-C, García-Sanz R, Ocio EM et al. The clinical utility and prognostic value of multiparameter flow cytometry immunophenotyping in light-chain amyloidosis. Blood 2011; 117: 3613-3616.

92 Muchtar E, Jevremovic D, Dispenzieri A, Dingli D, Buadi FK, Lacy MQ et al. The prognostic value of multiparametric flow cytometry in AL amyloidosis at diagnosis and at the end of first-line treatment. Blood 2017; 129: 82-87.

93 Gertz MA. Waldenström macroglobulinemia: 2017 update on diagnosis, risk stratification, and management. Am J Hematol 2017; 92: 209-217.

94 Waldenstrom J. Macroglobulinaemia. Acta Haematol 1958; 20: 33-39.

95 Owen RG, Treon SP, Al-Katib A, Fonseca R, Greipp PR, McMaster ML et al. Clinicopathological definition of Waldenstrom's macroglobulinemia: consensus panel recommendations from the Second International Workshop on Waldenstrom's Macroglobulinemia. Semin Oncol 2003; 30: 110-115.

96 Castillo J, Garcia-Sanz R, Hatjiharissi E, Kyle RA, Leleu X, McMaster M et al. Recommendations for the diagnosis and initial evaluation of patients with Waldenström Macroglobulinaemia: A Task Force from the 8th International Workshop on Waldenström Macroglobulinaemia. Br J Haematol 2016; 175: 77-86.
97 Paiva B, Corchete LA, Vidriales M-B, García-Sanz R, Perez JJ, Aires-Mejia I et al. The cellular origin and malignant transformation of Waldenström macroglobulinemia. Blood 2015; 125: 2370-2380.

98 Treon SP, Xu L, Yang G, Zhou Y, Liu X, Cao Y et al. MYD88 L265P somatic mutation in Waldenström's macroglobulinemia. N Engl J Med 2012; 367: 826-833.

99 Landgren O, Staudt L. MYD88 L265P somatic mutation in IgM MGUS. N Engl J Med 2012; 367: 2255-2256-2257.

100 García-Sanz R, Jiménez C, Puig N, Paiva B, Gutiérrez NC, Rodríguez-Otero P et al. Origin of Waldenstrom's macroglobulinaemia. Best Pract Res Clin Haematol 2016; 29: 136-147.

101 San Miguel JF, Vidriales MB, Ocio E, Mateo G, Sánchez-Guijo F, Sánchez ML et al. Immunophenotypic analysis of Waldenstrom's macroglobulinemia. Semin Oncol 2003; 30: 187-195.

102 Paiva B, Montes MC, García-Sanz R, Ocio EM, Alonso J, de Las Heras N et al. Multiparameter flow cytometry for the identification of the Waldenström's clone in IgM-MGUS and Waldenström's Macroglobulinemia: new criteria for differential diagnosis and risk stratification. Leukemia 2014; 28: 166-173.

103 Paiva B, Chandia M, Vidriales M-B, Colado E, Caballero-Velázquez T, Escalante F et al. Multiparameter flow cytometry for staging of solitary bone plasmacytoma: new criteria for risk of progression to myeloma. Blood 2014; 124: 1300-1303.

104 Avet-Loiseau H, Garand R, Lodé L, Robillard N, Bataille R. 14q32 Translocations discriminate IgM multiple myeloma from Waldenstrom's macroglobulinemia. Semin Oncol 2003; 30: 153-155.

105 Willenbacher W, Willenbacher E, Brunner A, Manzl C. Improved accuracy of discrimination between lgM multiple myeloma and Waldenström macroglobulinaemia by testing for MYD88 L265P mutations. Br J Haematol 2013; 161: 902-904.

106 García-Sanz R, Ocio E, Caballero A, Magalhães RJP, Alonso J, López-Anglada L et al. Post-treatment bone marrow residual disease $>5 \%$ by flow cytometry is highly predictive of short progression-free and overall survival in patients with Waldenström's macroglobulinemia. Clin Lymphoma Myeloma Leuk 2011; 11: 168-171.

107 Jelinek T, Hajek R. PD-1/PD-L1 inhibitors in multiple myeloma: The present and the future. Oncolmmunology 2016; 5: e1254856.

108 Seckinger A, Delgado JA, Moser S, Moreno L, Neuber B, Grab A et al. Target expression, generation, preclinical activity, and pharmacokinetics of the BCMA-T cell bispecific antibody EM801 for multiple myeloma treatment. Cancer Cell 2017; 31: 396-410.

109 Robillard N, Jego G, Pellat-Deceunynck C, Pineau D, Puthier D, Mellerin MP et al. CD28, a marker associated with tumoral expansion in multiple myeloma. Clin Cancer Res Off J Am Assoc Cancer Res 1998; 4: 1521-1526.

110 Robillard N, Wuillème S, Lodé L, Magrangeas F, Minvielle S, Avet-Loiseau H. CD33 is expressed on plasma cells of a significant number of myeloma patients, and may represent a therapeutic target. Leukemia 2005; 19: 2021-2022.

111 Lee KH, Seo HS, Sohn JY, Lee E, Lee H, Eom H-S et al. Abstract 3123: Aberrant expression of CD33 is associated with poor prognosis in patients with multiple myeloma and tumor progression. Cancer Res 2016; 76(14 Supplement): 3123-3123.

112 Gonsalves WI, Timm MM, Rajkumar SV, Morice WG, Dispenzieri A, Buadi FK et al. The prognostic significance of CD45 expression by clonal bone marrow plasma cells in patients with newly diagnosed multiple myeloma. Leuk Res 2016; 44: 32-39.

113 Pojero F, Flores-Montero J, Sanoja L, Pérez JJ, Puig N, Paiva B et al. Utility of CD54, CD229, and CD319 for the identification of plasma cells in patients with clonal plasma cell diseases. Cytometry B Clin Cytom 2016; 90: 91-100.

114 lqbal MS, Otsuyama K-I, Shamsasenjan K, Asaoku H, Mahmoud MS, Gondo T et al. Constitutively lower expressions of CD54 on primary myeloma cells and their different localizations in bone marrow. Eur J Haematol 2009; 83: 302-312.

115 Van Camp B, Durie BG, Spier C, De Waele M, Van Riet I, Vela E et al. Plasma cells in multiple myeloma express a natural killer cell-associated antigen: CD56 (NKH-1; Leu-19). Blood 1990; 76: 377-382.

116 Van Riet I, De Waele M, Remels L, Lacor P, Schots R, Van Camp B. Expression of cytoadhesion molecules (CD56, CD54, CD18 and CD29) by myeloma plasma cells. Br J Haematol 1991; 79: 421-427.

117 Rawstron A, Barrans S, Blythe D, Davies F, English A, Pratt G et al. Distribution of myeloma plasma cells in peripheral blood and bone marrow correlates with CD56 expression. Br J Haematol 1999; 104: 138-143.

118 Conticello C, Giuffrida R, Parrinello N, Buccheri S, Adamo L, Sciuto MR et al. CD200 expression in patients with Multiple Myeloma: another piece of the puzzle. Leuk Res 2013; 37: 1616-1621.

119 Tai Y-T, Dillon M, Song W, Leiba M, Li X-F, Burger P et al. Anti-CS1 humanized monoclonal antibody HuLuc63 inhibits myeloma cell adhesion and induces antibody-dependent cellular cytotoxicity in the bone marrow milieu. Blood 2008; 112: 1329-1337. 
120 Muccio VE, Saraci E, Gilestro M, Gattei V, Zucchetto A, Astolfi M et al. Multiple myeloma: New surface antigens for the characterization of plasma cells in the era of novel agents. Cytometry B Clin Cytom 2016; 90: 81-90.

121 Roussel M, Lauwers-Cances V, Robillard N, Hulin C, Leleu X, Benboubker L et al. Front-line transplantation program with lenalidomide, bortezomib, and dexamethasone combination as induction and consolidation followed by lenalidomide maintenance in patients with multiple myeloma: a phase II study by the Intergroupe Francophone du Myélome. J Clin Oncol 2014; 32: 2712-2717.

122 Paiva B, Chandia M, Puig N, Vidriales M-B, Perez JJ, Lopez-Corral L et al. The prognostic value of multiparameter flow cytometry minimal residual disease assessment in relapsed multiple myeloma. Haematologica 2015; 100: e53-e55.

123 Fukumoto K, Fujisawa M, Suehara Y, Narita K-T, Usui Y, Takeuchi M et al. Prognostic impact of immunophenotypic complete response in patients with multiple myeloma achieving better than complete response. Leuk Lymphoma 2016; 57: 1786-1792.
124 Attal M, Lauwers-Cances V, Hulin C, Leleu X, Caillot D, Escoffre M et al. Lenalidomide, bortezomib, and dexamethasone with transplantation for myeloma. $N$ Engl J Med 2017; 376: 1311-1320.

(c) (i)

This work is licensed under a Creative Commons Attribution 4.0 International License. The images or other third party material in this article are included in the article's Creative Commons license, unless indicated otherwise in the credit line; if the material is not included under the Creative Commons license, users will need to obtain permission from the license holder to reproduce the material. To view a copy of this license, visit http://creativecommons.org/licenses/ by/4.0/

(c) The Author(s) 2017 